\title{
MULTI-EDITORIAL
}

\section{Our Environmental Hopes for 1985-86 (continued)}

$\mathrm{F}$ eeling in the New Year less apprehensive than latterly about our biospheral prospects for the future, we asked for comments from chosen authorities on various en vironmental topics but, from the first few received and published on the initial four pages of this volume, were forced to conclude that our relative optimism had been ill-founded or at best premature. Now we follow with some more specialist opinions, from which readers may judge for themselves the validity or otherwise of our conclusions.

N.P.

\section{Land-use for Nutrition Security}

At the UN World Food Conference which was held in Rome in November 1974, optimism was expressed on the possibility of eradicating hunger by 1984 . Unfortunately this has yet to come about and indeed conservative estimates indicate that more than $\mathbf{4 0 0}$ million people may be going to bed hungry nowadays. Moreover the per caput food output is showing a declining trend, particularly in sub-Saharan Africa. In contrast, new technologies have generated hope in Asia and Latin America that food production can be kept ahead of population growth. But in spite of this progress, there is still a considerable degree of malnutrition and undernutrition in those continents as well as in Africa.

The task of building enduring National Nutrition Security Systems has therefore become urgent. Such a system should have the following six major components:

i) Food security, resulting in adequacy and stability of food supplies and economic and physical access to food.

ii) Drinking-water security, resulting in a reduction in the intestinal load of infections and in the incidence of diarrhoea, hepatitis, etc.

iii) Minimum income security, giving to all citizens the requisite purchasing power for balanced nutrition. Depending upon needs and possibilities, steps to ensure minimum income security may take the form of 'food-for-work' and 'food-for-development' programmes for unskilled and skilled labour, crop and livestock insurance for small farmers and share-croppers, mid-day meal and supplementary feeding programmes for children, and various other forms of social security measures for both economically handicapped farmers and consumers. The rights to food and to work have to become correlated rights. Developing countries cannot afford the advanced social security measures adopted by developed countries. Nevertheless, they have to realize that freedom from hunger can be achieved only by winning the battle against unemployment.

iv) Nutrition interventions, leading to protection of old and infirm persons, preschool children, and pregnant and nursing mothers, from undernutrition and malnutrition. Nutrition intervention programmes may also take the form of oral administration of vitamin $A$ and other special programmes to cater to specific needs.

v) Nutrition education, culminating in a widespread understanding that every family and every local community should and can solve its nutrition problems through due inclusion of suitable crops in the local land-use pattern.

vi) Population stabilization. In the ultimate analysis, a proper balance between population dynamics and resource availability is essential for improving the quality of life-including nutrition. Hence, population education and stabilization programmes have to become an integral part of a national nutrition-security action plan.

For achieving the above aims, scientific land-use based on sound principles of ecology and economics is essential. Land is a shrinking resource for agriculture. We know from the results of space exploration that we have to depend entirely upon the available land and water resources of Earth for feeding the present and future human and animal populations. There is still lack of awareness of the simple truth that the future of Mankind depends upon the health of our soils and waters. For example, while it takes a couple of centuries in Nature for the making of one centimetre of topsoil, several metres of good soil can be damaged within a short period of time to supply brick-kilns. Therefore, the task of creating an awareness of the need for scientific land-use is one of great urgency. It will be wise to follow the message contained in the following old Chinese proverb:

'If you are thinking one year ahead, plant rice;

If you are thinking ten years ahead, plant trees;

If you are thinking a hundred years ahead, educate the people."*

Monkombu S. Swaminathan, Director-General International Rice Research Institute

P.O. Box 933

Manila

Philippines;

President of IUCN; Councillor, WCB

\footnotetext{
* Earlier quoted in another form and context in our columns, but so appropriate here that we welcome its inclusion in these multiply eminent circumstances. - Ed.
} 


\title{
Employment and Development
}

Unemployment constitutes an intolerable injustice and an unacceptable waste of productive resources-resources that are needed inter alia to wage war on poverty and to ensure a basis for sustainable development. Unemployment is also a personal tragedy for the millions of people around the globe who are denied the elemental dignity of honest work. Unemployment is not the result of fate or natural laws but rather the product of wrong economic policies. Hence, the way to combat unemployment is to institute sound and viable policies for sustainable development.

Unemployment typically hits those people hardest who can least afford it, and whose position in society is weak for a variety of socio-cultural and economic reasons. We can measure unemployment statistically in the developed world, although there is still a substantial amount of 'hidden' unemployment*. But we cannot measure the human and social damages or the opportunity-costs involved. In the developing world the problem of labour-force measurement is staggering, particularly when it comes to measuring female employment.

Economic growth is needed in order to combat unemployment. But the fruits of economic growth do not automatically benefit those whose needs are greatest. Reasonably equitable distribution is a necessary-but in most cases unattainedbasis for sustainable development. During the high-growth periods of the nineteen-fifties and -sixties, we saw how too much of the labour force remained in low-productivity and low-income employment.

In most developing countries, recorded unemployment has been far higher for urban than for rural areas. However, the recording may be particularly poor in rural areas and underemployment remains as a major problem throughout the less-developed world. We need to create alternative employment to tilling the land in rural areas in order to protect the cities against immigration of the poor. Equally important, we need to find a way of pricing agricultural products in a manner which can make agriculture a fully viable source of employment in the developing world.

Sustainable development is ecologically sound development. We cannot indefinitely and mindlessly plunder the Earth; it must be managed intelligently and responsibly. Hence, we cannot treat environment as a mere afterthought or a consideration which we take into account when we can afford it. Nor can the human race as a whole afford to ignore its environment, which must be integrated into our developmental perspective in all economic and social activity as $a$ forethought.

It is possible to harness science and technology in ways which are favourable to the environment. Moreover, it is well within our power and competence to increase food production enormously, and to do so in ways that not only sustain but also expand the ecological basis for agriculture. We can develop energy, industrial processes, transportation, and human settlements, in manners which are consistent with sound environmental considerations. To the extent that choosing environmentally sound solutions often involves short-term expenditures which exceed those of a less responsible path, the rich countries should help to cover the additional costs of such investments in our common future.

Our world is an interdependent world, and our economies are interdependent economies. However, our mental appreciation is lagging dangerously far behind the facts. Let us consider an exemple: A decision in GATT (the United Nations' General Agreement on Tariffs and Trade) to restrict the market for goods where developing countries have an advantage such as cheap labour, can cripple those countries' development and blight their foreign currency reserves. Following the chain of cause-and-effect, we can see first a devaluation and then the local price of kerosene going up. Next, the pressures on fuel-wood resources increase and thereafter soil erosion increases and the basis for sustainable development shrinks again.

Our inadequate vision and parochial concerns constantly lead us down the alleys of sub-optimization and counterproductive strategies. Too often we are mortgaging our common future for some narrow short-term interest. Hence, we must learn to take the long view and the broad measurement. We must recognize that the less-developed countries face enormous difficulties in mobilizing resources for development. Their plight is often such that they are forced to give priority to prospects of a short-term nature. Choosing environmentally sound paths to development is a superior economy in the medium- and long-term, and ways must be found so to assist the developing countries that they can choose to invest in the future.

* as well as, of course, undeclared self and other employment.-Ed.

\author{
Gro Harlem Brundtland, Chairman \\ World Commission on Environment \& Development \\ Palais Wilson \\ 52 Rue des Pâquis \\ 1201 Geneva, Switzerland; \\ formerly Minister of Environment \\ and Prime Minister of Norway.
}

\section{$M A B$, Biosphere Reserves, and World Heritage Sites}

The Programme on Man and the Biosphere (MAB) (Batisse, 1980) is progressing satisfactorily in many countries of the world although the means available for the maintenance of networks of integrated field projects are clearly insufficient in a number of cases. The -International Coordinating Council for MAB met in Paris last December and took a number of decisions to foster the further implementation of the Programme. It established a scientific panel for programme orientation as well as a scientific panel for Biosphere Reserves (Batisse, 1982).

The most important recent event, however, was the adoption of the Plan of Action for Biosphere Reserves (comm. Batisse, 1985). This Plan of Action has since been endorsed unanimously by the Governing Council of UNEP at its 13 th 
Session, and by the Executive Board of UNESCO at its 121 st Session, while FAO and IUCN have also pledged their support for its implementation. At present there are 243 Biosphere Reserves in 65 different countries disposed practically throughout the world (Ibid., cf. map on page 17).

Biosphere Reserves provide a new tool for reconciling environment and development, and for ensuring systematic conservation of ecosystems and of the genetic resources which they contain. Their institution represents a distinct advance in Mankind's appreciative use of its habitat, but every effort should countinuingly be made to develop and enhance the international network of Biosphere Reserves, and to support the Action Plan at national and international levels.

In parallel, the implementation of the World Convention Concerning the Protection of the Cultural and Natural Heritage is making very good progress. Eighty-six countries have so far adhered to the Convention, and 186 natural or cultural sites have been placed on the World Heritage List. At its recent session in Paris, the Bureau of the World Heritage Committee has recommended inscription of an additional 28 sites. Significant contributions to the World Heritage Fund have recently been made or announced, including ones from France, Germany, the United Kingdom, and the United States.

\section{REFERENCES}

BATISSE, M. (1980). The relevance of MAB. Environmental Conservation, 7(3), pp. 179-84, map.

BATISSE, M. (1982). The Biosphere Reserve: a tool for environmental conservation and management. Environmental Conservation, 9(2), pp. 101-11, 8 figs.

Batisse, M. (comm. by) (1985). Action Plan for Biosphere Reserves. Environmental Conservation, 12(1), pp. 17-27, map.

Michel Batisse, Senior Environmental Adviser UNESCO

7 Place de Fontenoy

75015 Paris, France.

\section{Consider the Oceans}

Mankind is cramped onto the $29 \%$ of the Earth's surface which is land. His main use of the oceans that occupy the remaining area tends to be restricted to the shallow waters of the continental margins, where the chief resources of marine food and exploitable minerals occur. The much-publicized deep-water resource of manganese nodules etc. still remains untapped, and is likely to remain so for centuries. With the acceleration in the conservation crisis on land-resulting from the unchecked growth of human population, unrelenting increase in materialistic expectation in the rich countries, the exhaustion of easily-exploited resources of minerals, energy, and food, and our approach to the final limits of the Earth's carrying capacity which so far has been extended by technological 'Houdini-ism'-can we afford not to use the oceans more than currently in order to buy time in which our use of land can be rationalized?

Let me give two examples. The Krill (Euphausia superba) of the Southern Ocean offers a living resource with the potential to increase substantially the world's fish-catch-maybe even to double it. But can it be exploited without seriously damaging the populations of mammals and seabirds in the region? In this context, what is serious damage? Would the reduction of the Crabeater Seal (Lobadon carcinophagus) population by half be preferable to saving the starving humans in the Sahel or even subduing the aggression of advanced nations who can no longer feed their population? The choices are not clear-out, black and white choices but are between shades of grey which can only be distinguished if we can develop a fuller understanding, through environmental research, of the consequences of our actions.

There is a harder problem which is highlighted by the need to find a safe way to dispose of wastes-particularly high-level radioactive wastes from the nuclear power industries. Even with the maximum development of energy conservation and the use of renewable energy sources (which in themselves raise conservation problems), there will be continuing heavy dependence on traditional fossil fuels. Yet we are already seeing major problems resulting from the use of such fuels, for example in the destruction of forests and lake systems consequent on the complex interactions resulting from emissions of sulphur dioxide and nitrogen oxides.

Further in the future is the possibility that the elevation of atmospheric carbon dioxide levels will cause global climatic warming. The minimum effect of such warming is thought to be a poleward shift of climatic belts and a large-scale melting of polar ice. The environmental effects would be a substantial reduction in areas suitable for growing cereals and a rise in sea-level of around 7 metres. From this perspective the dangers associated with the generation of nuclear energy become relatively less worrying, especially if the problems of disposing of the dangerous waste which it produces can be resolved.

Land is precious, so perhaps it is time to examine objectively the option of using the deep ocean, especially as it is likely to be in the long-term interests of us all to curb our use of fuels which generate carbon dioxide. The oceans act as a buffer to many of these atmospheric changes. Exactly how, is uncertain; but it is important to discover how, because if we are approaching the capacity of the buffer, the changes could be much more sudden and dramatic than those predicted at present.

\author{
MarTin V. ANGEL \\ Highways \\ Vicarage Hill \\ Farnham \\ Surrey GU9 $8 \mathrm{HJ}$ \\ England, $U K$.
}




\section{Prospects for Desert Abatement}

On a world-wide scale, deserts are probably expanding faster today than ever before in the history of Mankind-faster even than they did between 1914 and 1934, which was a period in which more soil was lost to the world through erosion than in the whole of previous human history. That was the time when the dust-bowl of North America was created: the natural grasslands were ploughed up, imported cereals were harvested and, after a few years, the land lost its fertility. The topsoil, without cohesion, then blew away in dust-storms, and the land became desert (Cloudsley-Thompson, 1965). Much of that Man-made wasteland has since been restored, but at very considerable cost. In no conceivable circumstance, however, will similar remedial measures be applied to the vast areas of desertification in the Sahel savanna regions of Africa, to the expanding Thar desert of India, or to the numerous other regions of desert encroachment in the lessdeveloped countries of the Third World. The cost of such action would be phenomenal- $\$ 4.5$ thousand millions are needed annually over a period of 20 years merely to halt desertification. Nevertheless, this must be seen against the annual loss of agricultural production through desertification-a staggering $\$ 26$ thousand millions (Tolba, 1984). Even so, priority will almost certainly be given to armaments and defence-unless some miraculous changes take place in the minds and attitudes of politicians and administrators throughout the world!

There is a widespread, but largely erroneous, belief that desert expansion is caused by drought. This belief is extremely dangerous, because it deflects attention away from human responsibility for environmental deterioration. There have always been droughts and deserts, but only comparatively recently have normal climatic fluctuations led to starvation and death on so massive a scale as we have witnessed during the Sahel drought of 1968-73, and the present drought-which began in 1982 and triggered desertification in five continents during that year (Grainger, 1982).

Desertification is caused by overcultivation, overgrazing, deforestation, salinization, and bad irrigation - by taking too much from the soil and putting too little back. This, in turn, is the result of the human population explosion. Numbers of people are increasing as fast in arid and semi-arid lands as elsewhere in the world. The population of the Sahel, for instance, is enlarging at a rate of $2.5 \%$ per annum, while cereal production increases by only $1 \%$ a year, and there are few signs of any real progress against desertification. In those circumstances, the present catastrophe was inevitable. It is no exaggeration to claim that all the major problems which threaten mankind-starvation, disease, and war-are ultimately caused by population pressure (Cloudsley-Thompson, 1965).

The ways in which desert encroachment might be prevented have been outlined by Rapp et al. (1976), CloudsleyThompson (1978), and many others. They include human population control, transfer to other areas or activities, enforced emigration and education, as well as control over the use of land and water. Few existing Third World governments would, however, dare to tackle such inflammatory issues. Although the problem of desertification could undoubtedly be solved, implementation of the solution is blocked by social, political, and economic, factors. The deserts of the world will therefore continue to expand for a long time to come, and to think in terms of 'abatement' would be to retreat into the 'Cloud-cuckoo-land' of Aristophenes. The scientist in the field and in the laboratory is thoroughly capable of directing the battle against the desert. Scientific investigation must precede developments; but the problem of desert expansion is one of economics and ethics, rather than of science.

The present population explosion is probably the third to have taken place since our species evolved. The first supposedly resulted from the invention of cooking (which is so destructive of parasites), the development of agriculture, and the domestication of animals. The second began with the industrial revolution and was limited to the temperate regions of the Earth, but has continued into the present, third great world-wide increase in human numbers. The important question facing us today is whether our increasing population should be controlled, or left to the unavoidable consequences of inaction. It is difficult not to draw the conclusion that it is reaching a climax, and that a catastrophic crash may be imminent. This might well be caused by a large-scale nuclear war, by some new viral disease or stress syndrome, or by world starvation - as prophesied already long ago by Malthus (Cloudsley-Thompson, 1965). Desertification is one aspect of the last of these alternatives.

What little hope there may be for humanity lies in the fact that we are not so rational as we think. Despite our selfishness, greed, and stupidity, Mankind is strangely unique in being naturally compassionate.* By exercising this quality of compassion towards other human beings, and extending it to the fauna and flora of the world, we may yet overcome the dangers that are inherent in our temporary escape from the laws of Nature. This can be achieved, however, only by controlling our own reproduction. The unpleasant alternative is to allow our numbers to be reduced by arbitrary mortality factors and thus disregard responsibility for the control of our own destiny.

\section{REFERENCES} Cloudsley-Thompson, J.L. (1965). Animal Conflict and Adaptation. Foulis, London, and Dufour, Philadelphia: xi + 160 pp.,
illustr.

Cloudsley-Thompson, J.L. (1978). Human activities and desert expansion. Geographical Journal, 144(3), pp. 416-23.

Grainger, A. (1982). Desertification: How People Make Deserts, How People Can Stop, and Why They Don't. (An Earthscan Paperback, Ed. Jon Tinker.) International Institute of Environment and Development, London, England, UK: 94 pp., illustr.

Rapp, A., HouÉRou, H.N. LE \& Lundholm, B. (Eds) (1976). Can Desert Encroachment be Stopped? A Study with Emphasis on Africa.

\footnotetext{
${ }^{*}$ hence surely in considerable degree the conservation/environmental movement.-Ed.
} 
Programme and Secretariat for International Ecology, Stockholm, Sweden: 241 pp., illustr.

TolbA, M.K. (1984). Guest Editorial: A Harvest of Dust? Environmental Conservation, 11(1), pp. 1-2.

John L. Cloudsley-Thompson, Professor \& Head Department of Zoology

Birkbeck College (University of London)

Malet Street

London WCIE $7 H X$

England, UK,; Founder \& Editor,

\section{Conclusion}

Journal of Arid Environments.

The proverbial curate's egg having now been investigated further, we are forced to conclude that any good parts of it are unfortunately limited, and that the main source of hope is rooted in environmental education-provided its edicts can be implemented by suitable action on a sufficiently wide front and adequate scale. Thence in large measure comes the thrust of our World Council For The Biosphere with its twin sister the International Society For Environmental Education, which were both widely featured in our last Autumn issue, and see also the following Guest Editorial.

$$
\text { N.P. }
$$

\section{GUEST EDITORIAL}

\section{Some Overall Imperatives of the Environmental Education Movement}

\section{Introduction: The Troubled Background}

Environmental problems exist in all countries of the world, and at every state of economic development and political ideology. Third World countries frequently experience ills associated with underdevelopment or poorly-planned development. Often such problems result from poor farming techniques leading to soil erosion and depletion, improper management of forest resources, poor living conditions with respect to health and nutrition, vulnerability to natural disasters, and the lack of educational programmes to help them to resolve these problems. Other of the less-developed countries have adopted inappropriate measures based upon short-term gains or ones that are not suited to the existing situations. These adverse strategies have often led to the rapid depletion of resources, increased pollution, and in some instances to a decline in the standard of living and to concomitant spreading of disease.

Many developed countries, too, are faced with severe environmental problems. Some of their more critical situations include major industrial pollution, overexploitation of resources, and a variety of social and physical ills that confront their metropolitan areas.

When development programmes are not planned adequately, they may result in the deterioration of resources (such as the reduction in quantity and quality of mineral resources) or of those of the land, forest, or aquatic sites; biological pollution by organisms that may cause disease in humans, domestic animals, of crops; chemical contamination resulting from effluents, pesticides, or other materials; and physical pollution, such as of noise, silting, thermal wastes, or visual blight.

Such environmental problems cannot be resolved by considering only technological means; consideration must also be given to their social and economic roots. We will be facing the same environmental problems in the future and also breeding new ones-until we identify adequately their causes and develop specific and comprehensive programmes to resolve them.

It is evident that there can be no hope of a workable solution to environmental problems unless education is suitably modified to enable people from all walks of life to comprehend the fundamental interaction between humans and their environment, problems in this interaction, and potential changes to avoid or at least reduce these problems.

Within the attitudes and actions of our human population and its organizations, lie the behavioural roots of such ills as pollution, wasted energy, and the destruction of the environment. There is a general lack as yet of any global ethic effectively encompassing the world environment-an ethic which espouses attitudes and behaviours on the part of individuals and societies, and which should be consonant with humanity's place and critical role in The Biosphere.

In order to move towards a global ethic, I would like to outline a few environmental education imperatives for due consideration. These imperatives are representative of the thinking of many environmental educators in different regions of the world and have been expressed through thoughtful papers, meaningful discussions, meetings, proceedings of conferences, and publications. The ones that follow are not meant to be all-inclusive, but representative of some important thoughts which could be modified and expanded upon - to serve as guidelines for an action plan to improve the overall quality of our human environment.

\section{Some Environmental Education Imperatives}

1. Environmental Education should design programmes to reach effectively three major audiences, involving: (a) the world's general public, from early childhood through adulthood and beyond, in both the formal and the non-formal education sectors; (b) proper environmental education of specific professionals and social groups whose actions have an influence on the environment (engineers, architects, economists, planners, policymakers, manual workers, industrialists, etc.); and (c) the training of scientists, technologists, and other professionals who deal directly with environmental problems (agriculturists, horticulturists, foresters, biologists, hydrologists, ecologists, and yet others). 